\title{
Moral Discourse as Resource of Publicity: Religious and Secular Alternatives
}

\section{Elena Stepanova}

Institute of Philosophy and Law, Ural Branch of the Russian Academy of Sciences, Ekaterinburg, Russia

\section{Abstract}

In recent years, the defense of traditional values became one of the soundest strategies of religious authorities, as well as political powers in Russia. The author observes main arguments in the debates on traditional values presented by the hierarchs of the Russian Orthodox Church and political leaders, and figures out basic principles of the discourse: the "continuity" of the core values of Russian culture through its history; the opposition of Russia and "The West" as a significant

Corresponding Author: Elena Stepanova Stepanova.elena.a@gmail.com

Received: 26 April 2018 Accepted: 25 May 2018 Published: 7 June 2018

Publishing services provided by Knowledge $\mathrm{E}$

(c) Elena Stepanova. This article is distributed under the terms of the Creative Commons

Attribution License, which permits unrestricted use and redistribution provided that the original author and source are credited.

Selection and Peer-review under the responsibility of the ISPS Convention 2017 Conference Committee.

\section{G OPEN ACCESS} reference point, which seems to be a recurrent thing in Russian identity building; the indissoluble link between [traditional] religion and morality. The author concludes that significant shortcoming of the ideology of traditional values is that they exist only on a discursive level, not manifesting themselves in everyday moral practices, although should contribute to the formation of national identity. Hence, the 'traditional values' discourse is aimed at the cohering the nation around certain meanings that are assumed as obtaining both historical and ideological integrity.

Keywords: tradition, values, Russian Orthodox Church, morality, national identity.

\section{Introduction}

The discourse of traditional values occupies a place of honor in today's Russia, being an important source of forming new ideological consensus. Since the first half of the $2000 \mathrm{~s}$, it is possible to discern a gradual transformation of the ideological atmosphere in Russia, which could be defined as "the morality turn" [4]. The leading hierarchs of the Russian Orthodox Church (ROC) as one of so-called 'traditional religions' has been deeply involved in the debates on the role and place of traditional values in national identity of Russia's past and present, as well as in the discussion concerning the ROC's attitude toward other nations, religions, cultures, and morals. Thus, in recent years, the ROC has become an active promoter of 'traditional values' both inside Russia and internationally. 
The influence of the Orthodox interpretation of traditional values over wider public should not be underestimated since a considerable number of Russians see religion (Orthodoxy in particular) as a cultural symbol of the country and ready-made tool for teaching morality. In other words, "morality seems to be the most natural and convenient discursive space in which a religious body can contribute to public debates. It is the field in which communication and negotiation between the religious and the secular can easily take place and in which 'comprehensive doctrines' can be translated into a commonly detectable language" $([2], 3)$. At the same time, the ROC tends to attribute herself an exclusive role in the sphere of culture and morality. According to Igumen Philip (Ryabykh), "Today religions try to preserve their freedom not only in an exclusive way, by claiming that some norms may not apply to religious communities, but they also insist on their right to contribute to the shaping of general norms that apply to the whole of society." ([10], 23). Kristina Stoeckl stresses that it is typical for the defenders of moral traditionalism to be involved into public debates thus becoming political actors [13].

The idea of an indissoluble link between [traditional] religion and morality is strongly supported by the Russian political powers, which tend to delegate the responsibility for moral improvement of Russian people to religious institutions. As a result, in recent decades, the religiosity and moral traditionalism's alliance has substantially increased. Thus, religion in Russia "now became a direct, unhampered source of morality. It would be a gross exaggeration to say that in today's Russia religion defines the popular ethos; however, it unquestionably a major factor not only for those who regularly practice and observe religion, but it is also an important and esteemed reference point for a massive part of the non-religious population' $([1], 17)$

\section{The Score of Traditional Values and Basic Principles of Their Defense}

What do the ROC authorities mean by traditional values, and what are their origins? Patriarch Kirill lists the universal values of 'faith, love, duty, responsibility, solidarity'. From his perspective, these eternal values are not the product of the historical evolution, and they do not depend on particular socio-cultural conditions; they are not created by people, but are embedded into the human nature by God. These values are not particularly Christian, because they are built into the structure of the universe and traced back to the first steps of the humankind. Kirill insists: "We [Russians] share these values with many morally healthy people who do not consider themselves as 
adherents of any religion and live according to the law of conscience". Accordingly, the rejection of traditional values leads to the destruction of human beings and society [6].

President of Russia Vladimir Putin during his third turn seems to shift from the initial refrain from the official state ideology toward the promotion of the new national ideological consensus based on the moralistic approach, which includes traditional values as its core element. In the annual Presidential Address to the Federal Assembly in December 2013, Putin promised to defend traditional values "that have made up the spiritual and moral foundation of civilization in every nation for thousands of years: the values of traditional families, real human life, including religious life, not just material existence but also spirituality, the values of humanism and global diversity" [9]. In Putin's interpretation, traditional values have transcendent character; they are understood in an essentialist way as eternal and unchangeable, thus being applicable not only to Russia but to other countries as well. In addition, the reference to "every nation for thousands of years" indicates that Putin's message is addressed not just to the Russian citizens, but also to more and more people in the world who support his position.

It is important to note that for both Putin and Kirill, the scale of traditional values is much wider than the opposition to same-sex marriages, the LGBT agenda, and the defense of traditional family (although all this themes are constantly present in the rhetoric of both religious and secular defenders of traditional values). Generally, traditional values are interpreted as the ultimate moral foundation of human life. Both secular and religious protagonists of traditional values use to place them within broader context - namely, the distinctiveness of the Russian culture and religion comparing with European countries and the USA, which are generalized as 'the West'. The picturing of Russia as the world's last bastion of the defense of traditional values is an integral part of the idea of the ongoing conflict between two opposite civilizations: Western (secular) and Orthodox (genuine Christian), where the former stands for liberalism, secularism, and individualism, while the latter represents traditionalism, moralism, religion and community [12]. The idea of Russia as a separate civilization presupposes that tradition is the way to preserve the nation's culture, which must be protected from foreign influences. The ROC as protagonist of traditional values views Russia as a great nation with an exclusive divine appointment to defend Christian civilization as such. Thus, for the first time since the collapse of Marxism-Leninism, Russia is offering the world a narrative that goes beyond its national specificities, has universal value, and thus can be accepted, integrated, and reinterpreted in other contexts [4]. 
What does tradition mean in both the today's Orthodox and secular rhetoric? In the Orthodox discourse, it means the ecclesiastic canonical tradition, the Predanie (Greek paradosis), which signifies the inherited sum of texts, ideas, norms and customs [2]. According to Patriarch Kirill, 'for the Orthodox Christian, tradition is a set of creedal and moral truths that the Church has accepted from the testimony of the Apostles and which it has guarded and developed as a function of the historical circumstances' ([5], 3). In a secular sense, tradition has been mainly associated with morality.

The discourse of traditional values is based on certain principles [11]. The first is the adjustment of the past to the current political and ideological needs. The overall principle of the symbolic appropriation of the past - the "continuity" - was proclaimed by Vladimir Putin in the annual Presidential Address to the Federal Assembly in December 2012: "We need to link historical eras and get back to understanding the simple truth that Russia did not begin in 1917 or even in 1991, but rather, that we have a common, continuous history spanning over 1000 years and we must rely on it to find inner strength and purpose in our national development" [8]. The Orthodox version of the principle of 'continuity' is based on the combination of tradition and Predanie. It constitutes the Russian nation in opposition to the Western liberalism, which brings 'the expansion of alien, destructive social and cultural factors..., and the new way of life that is arising and taking shape outside of any tradition under the influence of today's post-industrial world' ([5], 6). Thus, according to the principle of 'continuity', the core values of the Russian culture remain unchanged through its history despite radical breaks with tradition. Thereby, traditional values obtain the qualities of eternity and consistency; they provide "continuity" and do not depend on caprices of history.

The second principle is the opposition of Russia and "The West" as a significant reference point, which seems to be a recurrent thing in Russian identity building. Thus, Putin constantly underlines the antithetical opposition between liberal tolerance and secularism of the West and morality and organic unity of Russia. He argues that that many Euro-Atlantic countries have moved away from their roots, including Christian values and traditional identities. In opposition to European countries, Putin confirms that defending traditional values "is absolutely objective and understandable for a state like Russia with its great history and culture, with many centuries of experience, not so-called tolerance neutered and barren, but the actual common natural life of different peoples within the framework of a single state" [9].

As for Patriarch Kirill, 'the most fundamental conflict of our present era is the clash between the liberal model of civilization on the one hand and national, cultural and religious identity, on the other' [5]. Kirill argues that secular liberalism supports the 
idea of emancipation of the sinful individual who rejects anything that binds him and prevents from the affirmation of his sinful self. Human freedom becomes a supreme value, but only as a freedom of choice. The situation when each person is free to determine the scale of moral values, on which he or she relies, leads to a radical rejection of normative values. According to Kirill, the principal aim of the West is to expel religion from society and to diminish the influence of religion on people's behavior and life.

The principle of "continuity" seems to be more complex in the Russian Orthodox interpretation of the history of Russia then in the secular one. The main ambiguity is the understanding of the Soviet period, which is estimated as 'godless and god-fighting', being the period of history when the Russian Orthodox Church had suffered from state repressions more than anybody else. In fact, the atheistic Soviet state was not friendly toward religion; indeed, it could be hostile. Nevertheless, it seems that for the ROC's leaders 'continuity' as the ideological principle surmounts the breaks. Paradoxically, the very reference to the 'godless' Soviet power, which has put the Church into a humiliating and dependent status, as well as the experience of the survival, ensures the symbolic right of the Church to serve as the sole depositary of the spiritual heritage of the Russian people. The 'godless' Soviet power proves the ROC's trustworthiness in the times of "the monstrous experiment", and allows it to function as an intermedium of "continuity" [11].

At the same time, the ROC has assumed some substantial elements of the late Soviet ethos in the sphere of morality [7]. As Alexander Agadjanian notes, the affinity between the Orthodox moral didactic and the late Soviet ethos "is largely based upon a common negative assumption - namely, a rejection of the imagined 'western liberal ethos'... Such paradigmatic conservatism had been celebrated as constitutive to the Russian civilization's uninterrupted religious inheritance" ([2], 43).

It seems that the conviction of the inseparable connection between religion and morality is a relic of the Marxist-Leninist concept of society, with its division of social life into a material and spiritual component and with the attribution of religion and morality to the spiritual sphere. In the theological sense, the statement about the connection between religion and morality is inorganic for the Orthodox tradition, rather, it distinguished Western European Protestantism of the late XIX - early XX century with the interpretation of Christ as the teacher of morality. Nevertheless, this statement is very beneficial for Orthodoxy, acting as a means of legitimizing her social role in modern Russia and at the same time allowing her to position herself before the West as the guardian of an authentic Christian tradition. 
As for the concept of "the West" as the enemy, it is deeply embedded within Orthodox self-consciousness and modes for self-expression. In the same way, in the Soviet times, the West was described as inherently immoral capitalist system of exploitation, thus affirming the moral superiority of the USSR. The comparison with the West is an intrinsic part of both secular and religious statements concerning traditional values. It seems that without referring to "the West" as enemy they would simply lose their substance. Negative stereotypes and enemy images seems to be crucial for the Russian way of constructing national identity. The purpose of the image of "the West" as an existential enemy is to strengthen Russia's distinctiveness as the defender of traditional values on behalf of the humankind, to mobilize the people of Russia, and to unite them around political power and religious authorities, which guarantee security and stability. In other words, the defense of traditional values is typically based on the disclosure of an "enemy" and the threat that this enemy poses toward the maintenance of such values rather than on a demonstration of their merits; consequently, the traditional values discourse lacks the necessary cogency to serve as a basis for ideological consensus.

\section{Traditional Values Versus Moral Autonomy}

As it has been mentioned above, the defenders of traditional values contrapose the "Western" concept of freedom as a freedom of choice to Russian idea of free embracement of the eternal moral truth preserved by tradition and supported by Orthodoxy. The idea that the Western liberal understanding of freedom as arbitrariness opposes the Orthodox concept of freedom as voluntary obedience to God's truth is the basis of Kirill's critique of liberalism, which leads to "a radical rejection of the normative significance of tradition, especially religious tradition, and to the absolute right of an individual to determine what is good and what is evil" ([5], 11).

Indeed, the Western society of the era of modernity is associated with the idea of moral autonomy of the individual and, accordingly, with the recognition of freedom of choice as the main humanistic value. As the classics of Western sociology emphasized, in traditional pre-modern society, morality was wholly based on religion and was supported by collective representations that surpassed any individual ones. Morality was perceived as something transcendent, as an attribute and emanation of the divine principle, thereby appearing beyond criticism. Man carried moral obligations not before other people, but before God (gods) and had to fulfill the rules prescribed from above. 
However, gradually relations between people became more complicated, and human moral obligations became independent of religious grounds. The fact that the moral norms in the past had a religious justification did not at all mean that they could not now be expressed in any other way. Western society consistently got rid of the idea of the sacred, quasi-religious nature of morality, finding in it what could have been called by its own name and justified without resorting to a supernatural beginning.

At the same time, the secularization of morality did not mean simply replacing religious concepts with secular ones, because some moral ideas have merged so much with religious ones that it became impossible to separate them from each other. Rather, one could speak about gradual detection of moral principles hidden in religious concepts. In the era of modernity, morality gradually became a condition for the constitution of society as a system of relationships based on solidarity and the harmonization of mutual interests. Thus, in a society of modernity, morality ceased to be a once and for all established set of norms that have a sacred nature.

However, from the Orthodox point of view, the secular worldview of the presentday society is destructive for morality, since it has introduced the image of a person who is completely turned to the earthly world and is in captivity of his/her passions. The common good, social solidarity and mutual assistance are secondary, because the main thing is satisfaction of everyday needs and desires.

Thus, we have here two opposing positions in many respects: if liberal social thought regards morality as a product of personal autonomy and as a positive factor of social development, then, according to the Orthodox point of view, absolutizing freedom of choice destroys morality, turning it into an arbitrariness. In this contradiction, the natural discrepancy between secular and religious notions of morality is clearly manifested: if the former by their nature admit moral pluralism as a consequence of personal autonomy, the latter proceed from the absolutization of their own system of values, which requires collective adherence.

The problem arises when a religious point of view claims to be an absolute truth in a secular society. In this case, the religious institution appropriates power functions and monopolizes the right to determine what is morally good, and what is not. Thus, the traditional values of a particular religion become an ideology imposed from above and does not require people to do anything but to agree with their authority. There is a situation of "compulsion to traditional values", which is an obstacle to the transition from declared values to the real everyday moral choice of a person, since it does not require individual responsibility for decisions and deeds. 
It should be emphasized that moral consciousness as expression of autonomous will can by no means be introduced from above, since in this case it is not a matter of morality but of external compulsion to comply with conventional social norms. A moral individual does not have to be a believer or an unbeliever, but he/she can be one or the other in accordance with his/her free choice. In addition, the attribution of morality to the competence of the Orthodox religion does not automatically contribute to the emergence of a moral personality simply because most people in Russia perceive Orthodoxy as a cultural symbol, which does not imply the personal moral choice.

A significant shortcoming of the ideology of traditional values is that they exist only on a discursive level, not manifesting themselves in everyday moral practices; although they are supposed to contribute into formation of national identity, continuity in the course of social transformations and curing related traumas. The very presence of the topic of traditional values in the public space of modern Russia testifies the thirst for reliable value orientations that could give meaning to people's lives. However, today the discourse of traditional values is either religious or secular form only emphasizes the gap between the declarative values constantly spoken by political and religious figures and the everyday moral values that determine the people's life practices.

\section{Conclusion}

In general, the concept of traditional values is used by both secular powers and religious authorities to ideologically consolidate Russian society, and at the same time to recruite potential allies in the international arena.

Nevertheless, the presence of traditional values in Russian public discourse being a significant resource of publicity reveals serious controversies in the search for a new national identity, as well as the lack of any reliable common values that might give meaning and structure to everyday life of citizens. The identity crisis that has persisted in Russia since the disintegration of the Soviet Union with its system of collective values and symbols is characterized by particularism - that is, by the multiplication of identities (social, ethnic, family, etc.). Hence, the "traditional values" discourse is aimed at the cohering the nation around certain meanings that are presented as having both historical and ideological integrity. The question is whether this artificial construction based on noncontroversial "continuity" of history and opposition to various "enemies", could be convincing enough for the Russian people. 


\section{References}

[1] Agadjanian, A. 2011. "Exploring Russian Religiosity as a Source of Morality Today." In Multiple Moralities and Religions in Post-Soviet Russia, edited by Jarett Zigon, 16-26. New York - Oxford: Berghahn Books.

[2] Agadjanian, A. 2017. "Tradition, Morality and Community: Elaborating Orthodox Identity in Putin's Russia." Religion, State and Society, 45 (1): 39-60.

[3] Curanovic', A. 2014. "Weaknesses of the Post-Soviet Religious Model: The Kremlin and 'Traditional' Religions in Face of Interethnic Tensions in Russia". Politics and Religion, 7 (4): 788-817.

[4] Laruelle, M. 2014. "Beyond Anti-Westernism: The Kremlin's Narrative about Russia's European Identity and Mission". PONARS Eurasia Policy Memo No. 326. Retrieved from: $\quad$ http://www.ponarseurasia.org/sites/default/files/policy-memos-df/ Pepm326_Laruelle_August2014.pdf

[5] His Holiness Kirill, Patriarch of Moscow and All Russia. 2011. Freedom and Responsibility: A Search for Harmony - Human Rights and Personal Dignity. London: Darton, Longman \& Todd; Moscow: Publishing House of the Moscow Patriarchate.

[6] Kirill. 2014. - "Vystuplenie Sviateishego Patriarkha Kirilla na Rozhdestvenskikh parlamentskikh vstrechakh v Sovete Federatsii RF" [His Holiness Patriarch of Moscow statement for the Christmas parliamentary meeting in the Federal Assembly of the Russian Federation]. The Russian Orthodox Church: official site of the Moscow Patriarchate. Retrieved from: http://www.patriarchia.ru/db/text/3544704. html

[7] Kruglova, T., and Litovskaya, M. "Sovetskij mir: konformizm i konformisty" [Soviet world: conformism and conformists]. Vestnik Permskogo universitets, ser. Istoria, $30(3): 67-73$.

[8] Putin, V. 2012. "Address to the Federal Assembly". Retrieved from: http://eng. kremlin.ru/transcripts/4739

[9] Putin, V. 2013. "Presidential Address to the Federal Assembly". Retrieved from: http: //eng.kremlin.ru/news/6402

[10] Ryabykh, F. 2013. "New Challenges to Religious Freedom in Europe." In Freedom of Religion or Belief in Foreign Policy: Which One? Edited by Pasquale Annicchino. San Domenico di Fiesole: European University Institute.

[11] Stepanova, E. 2015. "'The Spiritual and Moral Foundation of Civilization in Every Nation for Thousands of Years': The Traditional Values Discourse in Russia." Politics, Religion \& Ideology, 16 (2-3): 119-136. 
[12] Stoeckl, K. 2012. "The Human Rights Debate in the External Relations of the Russian Orthodox Church". Religion, State \& Society, 40 (2): 212-232.

[13] Stoeckl, K. 2016. "The Russian Orthodox Church as Moral Norm Entrepreneur". Religion, State and Society, 44 (2): 132-151. 